\title{
Evaluation of Bio-controlling Agents against Potato Foliar Pathogens
}

\author{
Jayashree Bhattacharjee $^{1 *}$, Debashre Bhattacharjee ${ }^{2}$ and Amitava Basu ${ }^{3}$ \\ ${ }^{1}$ Department of Plant Pathology, Bidhan Chandra Krishi Viswavidyalaya, \\ West Bengal- 741 252, India \\ ${ }^{2}$ Agricultural Technology Management Agency, Govt. of Tripura, India \\ ${ }^{3}$ Division of Plant Pathology, Bidhan Chandra Krishi Viswavidyalaya, West Bengal-741 252, \\ India \\ *Corresponding author
}

\section{A B S T R A C T}

\section{Keywords}

Potato disease, Foliar fungi, Biocontrol,

Trichoderma sp, Bacillus sp.

Article Info

Accepted:

12 February 2019

Available Online:

10 March 2019
Bio-controlling of potato foliar pathogens could be an alternative and eco-friendly management. Therefore, in this trial, the antagonistic potential of some bio-controlling agents (BCAs) of Trichoderma spp. (Trichoderma asperillum, Trichoderma longibrachiatum and Trichoderma harzianum) and Bacillus spp.(Bacillus cereus, Bacillus siamensis, Bacillus amyloliquefaciens, Bacillus safensis, Bacillus subtilis, Bacillus flexus and Bacillus megaterium) were assessed against six foliar pathogens of potato origin (Alternaria solani, Alternaria alternata, Phomaexigua, Curvularia lunata, Bipolaris sorokiniana and corynospora cassicola) through in vitro and in vivo trials. Trichoderma harzianum and Bacillus subtilis were better than other BCAs against the pathogens. The overall inhibition was 39.2-79.2\% with Trichoder maharzianum and $26.7-70.7 \%$ with Bacillus subtilis. Under glasshouse condition, the infection was best controlled with Trichoderma harzianum soil treatment @ $10 \mathrm{~g} / \mathrm{kg}+$ Bacillus subtilis seed treatment @ 10 $\mathrm{g} / \mathrm{kg}$ following foliar application of pathogen @ 45 days of planting. From this, it was concluded that BCAs could effectively be used for controlling the infection of potato foliar diseases. Hence it is recommended for sustaining potato farming. Further study on validation of above findings through location specific field trials is recommended.

\section{Introduction}

Potato (Solanum tuberosum L.) is a staple food crop for millions of people to fight against malnutrition and hunger. But its worldwide annual production is reducing due to diseases of bacterial, fungal, viral and physiological kind (Kehr et al., 1964). Foliar pathogens are of greatest concern among these diseases. Foliar pathogens affect the yield through hampering the photosynthetic ability of the leaves (Rotem, 1994). Among the foliar diseases, early blight is most serious and devastating; it lends both quantitative and qualitative loss (CIP, 1996). Besides potato, it affects but also tomato, chilli, eggplant and many other cultivated and wild plants. Early blight occurs due to Alternaria solani and $A$. alternate which are air-borne microbes with wide host range (Pandey and Vishwakarma, 
1998). Early blight appears as dark brown to black concentric rings on leaves, which later produces a target board effect. They are difficult to control and presently few cultivars possess resistance against these pathogens. Early blight occurs at all potato growing areas, but its significance could notice only in warm and wet weather when the pathogens multiply faster and spread rapidly (Hausladen and Leiminger, 2011).

The other important foliar diseases occur due to Phomaexigua, Curvularia lunata, Bipolaris sorokiniana etc. Phoma lends $20 \%$ loss particularly during Kharif season (Gupta, 2007) and C.lunata causes $16 \%$ loss through foliar necrosis. B. sorokiniana affects many other crops besides potato. Therefore, it is of utmost importance to control these pathogens to sustain the potato production.

The use of chemical fungicides reduced the infection level (Djébali and Belhassen, 2010), but chronic treatment with these fungicides lead to the emergence of resistant strains. In addition, the use of these chemical fungicides is costly for farmers, human health and environment (Vurro and Gressel, 2006). As a consequence, it is discouraged. Recently, the trend is diverted towards biological measures (Mishra and Singh, 2012).

In biological measures, new or resident living organisms are purposefully used to suppress the activity of pathogens by direct/indirect manipulation of reproduction of microorganisms (Pal and Gardener, 2006). A number of bio-controlling agents (BCAs) are available. But Trichoderma sp. and Bacillus $\mathrm{sp}$. are the most promising because of its wide host range and environmental conditions (Chen et al., 1983). Therefore, the present study has been undertaken on the efficacy of BCAs of Trichoderma sp. and Bacillus sp. against pathogenic foliar fungi of potato origin.

\section{Materials and Methods}

The study was conducted in the Department of Plant Pathology, Bidhan Chandra Krishi Viswavidyalaya (BCKV), Mohanpur, West Bengal. For routine phytopathological and analytical works, standard literatures were followed.

The test pathogens namely $A$. solani, $A$. alternata, $P$. exigua, $C$. lunata, $B$. sorokiniana and $C$. cassicola were isolated from potato leaves having the disease symptoms through tissue segment method (Rangaswami, 1958). The morphological identities of the isolated fungi were confirmed using the text of Booth and Sutton (1984) and Chowdhry et al., (2000). Reproducibility of disease reaction/virulence by the isolates was confirmed following the detached leaflet technique (Foolad et al., 2000) on potato cultivar var. Kufri Chandramukhi.

BCAs used were Trichoderma asperillum, Trichoderma longibrachiatum, Trichoderma harzianum, Bacillus ceresus, Bacillus siamensis, Bacillus amyloliquefaciens, Bacillus safensis, Bacillus subtilis, Bacillus flexus and Bacillus megaterium among the spp. They were procured from Indian Institute of Oil Seed Research (IIOR), Telangana. Trichodermas spp. were sub-cultured in PDA and preserved at $5^{0} \mathrm{C}$. Bacillu sspp. were subcultured in NAS following the aseptic technique. The cultures were renewed at 10 days interval to maintain the purity and potency.

The antagonistic potential of Trichoderma against the test pathogens was assessed through the dual culture technique (Morton and Straube, 1955). Both pathogen and Trichoderma were belonging to same age while testing. $6 \mathrm{~mm}$ diameter blocks of the pathogen and Trichoderma were inoculated at the same time on the opposite sides of the 
PDA in petriplates (9 $\mathrm{cm}$ dia.). Then, the plates were incubated at $28 \pm 1^{0} \mathrm{C}$ for 8 days. In each test, a control plate was maintained to compare the result. The antagonistic ability of Trichoderma was assessed on the modified Bell's scale (Bell et al., 1982). The hyphal interactions were assessed by growing them on the cellophane membrane placed over the solidified PDA (Dennis and Webster, 1971). Both the fungi when came into contact to each other, the contact zone was cut using sterile scalpel and taken out along with the cellophane. Then, it was gently washed with sterile distilled water, mounted under $0.1 \%$ lactophenol cotton blue over a clean glass slide and observed under a microscope. The hyphal interaction was photographed.

For in-vitro assessment of Bacillus spp., sterile PDA was poured into the sterilized petri-plates. After solidification of the medium, a loop of 24-48 hrs, old culture was taken from slants and streaked on one side of the plate. Fungal plugs were carefully placed on the opposite side of the bacterial streak. Both the bacteria and fungi of same age were used. Incubation was done in a BOD incubator at $30 \pm 2^{0} \mathrm{C}$ for $3-4$ days. The length of fungal and bacterial growth and zone of inhibition was measured using a scale (mm). In each test, one control plate was maintained for comparison.

After in vitro assessment, the BCAs were evaluated under glasshouse condition in polythene bags $\left(\begin{array}{lll}30 & \text { x15 } & \mathrm{cm}\end{array}\right)$ against Alternaria sp. following Thilagavathi et al., (2007) and Abeysinghe (2009). Briefly, a talc-based formulation was first prepared. For seed treatment, the tubers were mixed with the formulation (@10 g/kg of seed) and sheddried (Nandakumar et al., 2001). For soil treatment, the talc-based formulation was mixed with soil (@10 g/kg). And then seed tubers hand dipped into each polythene bag. The plants were watered daily @ $50 \mathrm{ml} /$ bag.
The design of experiment followed was completely randomized block design (CRBD) with two replicates for each combination. The percent disease index (PDI) was calculated following Mayee and Datar (1986).

\section{Results and Discussion}

\section{Antagonistic potential of bio-control agents}

AllTrichoderma spp. showed antagonistic effect on potatofoliar fungi, that is- $A$. alternata, A. solani, C. cassicola, C. lunata, $B$. sorokianaand $P$. exigua (Plate-1).The inhibition was varied from $54-72 \%$ in $A$. alternate (Figure 1a). Maximum inhibition (72\%) has shown by T. harzianum, followed by $T$. asperillum (viridae) and $T$. longibrachiatum. The inhibition was 49.2$76 \%$ in A. solani (Figure 1b). Maximum inhibition (76\%) was shown by T. harzianum, followed by $T$. longibrachiatum (56.0\%) and T. asperillum (49.2\%). The inhibition was $39.2-71.2 \%$ in $C$. lunata (Figure 1c). Maximum inhibition was shown by $T$. harzianum (71.2\%) followed by $T$. longibrachiatum and $T$. asperillum. The inhibition was $74.0-79.2 \%$ in C. cassicola (Figure 1d). Maximum inhibition was shown by $T$. harzianum $(79.2 \%)$ followed by $T$. asperillum (viridae) and minimum (74.0\%) by $T$. longibrachiatum.

The inhibition was $41.2-59.2 \%$ in $B$. sorokiniana (Figure $1 \mathrm{e}$ ). Maximum inhibition was shown by T. harzianum (54.9\%) followed by $T$. longibrachiatumand T. asperillum. The inhibition rate was $67.2-79.2 \%$ in $P$. exigua (Figure 1f). Maximum inhibition was shown by $T$. harzianum (79.2\%) followed by $T$. longibrachiatum and T. asperillum. The direct mycoparasitic activity of Trichoderma is one of the major mechanisms involved in this inhibition effect (Bruce et al., 1995; Haran et al., Pandey (2010). 
Similarly, all Bacillus BCAs such as $B$. cereus, B. siamensis, B. amyloliquefaciens, $B$. safensis, $B$. subtilis, $B$. flexusand $B$. megaterium showed antagonistic effect on the test pathogens, i.e., A. alternate (Plate-2.a), A. solani (Plate-2.b), C. lunata (Plate-2.c), $C$. cassicola(Plate-2.d), B. sorokiana (Plate-2.e) and $P$. exigua (Plate-2.f) during in vitro assessment. The inhibition was $27.45-52.72 \%$ in A. alternate (Figure 2a), 26.75-56.60\%, in A. solani (Figure 2b), 34.83-66.02\% in $C$. lunata (Figure 2c), 48.30-68.51\% in $C$. cassicola (Figure 2d), 29.46-45.53\% in $B$. sorokiniana (Figure 2e) and 56.55-70.75\%, in $P$. exigua (Figure 2f). This corroborated the findings of Souja et al., (2014) and Abdallah et al., (2015). This inhibitory effect could be attributed to secretion of hydrolytic enzymes (Fujimoto and Kupper, 2016.), peptide antibiotics (Mannanov and Sattarova, 2001), mycosubtilin, and zwittermicin (Pal and Gardener, 2006), volatile extracellular metabolites (Podile et al., 1987), mycosubtilin, and zwittermicin (Pal and Gardener, 2006). Maximum inhibition shown by $B$. subtilis was due to secretion of Fengycin and bacillomycin (Cao et al., 2011) and by $B$. amyloliquefaciens was due to gpolyglutamic acid synthesis(Liu et al., 2010).

During the in vitro assessment, $T$. harzianum and B. subtilis were better than other BCAs against the pathogens in terms of inhibition of mycelial growth. Thus they were assessed under glass condition in various combinations against Alternaria sp. following the foliar application of pathogen at 45 days after planting (DAP). The magnitudes of PDI and crop yield were varied from treatment to treatment (Table 1, Plate 3). PDI was $8.5 \%$ with T. harzianum soil treatment @ $10 \mathrm{~g} / \mathrm{kg}+$ seed treatment with B. subtilis @ $10 \mathrm{~g} / \mathrm{kg}$, $11.1 \%$ with seed treatment with $T$. harzianum @ $10 \mathrm{~g} / \mathrm{kg}+$ soil treatment with $B$. subtilis @ $10 \mathrm{~g} / \mathrm{kg}, 12.0 \%$ with soil treatment with $T$. harzianum @ $10 \mathrm{~g} / \mathrm{kg}, 12.2 \%$ in healthy plant with no treatment, $13.4 \%$ with seed treatment with B. subtilis @ $10 \mathrm{~g} / \mathrm{kg}, 15.5 \%$ with seed treatment with T. harzianum @ $10 \mathrm{~g} / \mathrm{kg}$ and $16.4 \%$ with B. subtilis soil treatment @10 $\mathrm{g} / \mathrm{kg}+$ foliar application of pathogen when compared with $20.4 \%$ in healthy plant with disease inoculation. The yield was $125.1 \mathrm{~g} / \mathrm{pot}$ with T. harzianum soil treatment @ $10 \mathrm{~g} / \mathrm{kg}+$ seed treatment with B. subtilis@ @ $10 \mathrm{~g} / \mathrm{kg}$, $95.15 \mathrm{~g} /$ pot with seed treatment with $T$. harzianum@10 g/kg + soil treatment with $B$. subtilis @ $10 \mathrm{~g} / \mathrm{kg}, 92.80 \mathrm{~g} / \mathrm{pot}$ with soil treatment with $T$. harzianum @ $10 \mathrm{~g} / \mathrm{kg}, 88.65$ $\mathrm{g} /$ pot with seed treatment with $B$. subtilis 10 $\mathrm{g} / \mathrm{kg}, 71.30 \mathrm{~g} / \mathrm{pot}$ with soil treatment with $T$. harzianum @ $10 \mathrm{~g} / \mathrm{kg}, 71.30 \mathrm{~g} /$ pot with seed treatment with T. harzianum @ $10 \mathrm{~g} / \mathrm{kg}$ and $82.60 \mathrm{~g} /$ pot in a plant with in treatment (negative control) when compared with the yield of $62.60 \mathrm{~g} / \mathrm{pot}$ in plant with disease inoculation (positive control). This indicated that the $T$. harzanium soil treatment $+B$. subtilis seed treatment is most effective against the infection of Alternaria sp. This corroborated the findings of Suleiman et al., (2016) and Rani et al., (2017).

Seed treatment with B. subtilis has reduced the disease outbreak through microbial competition, antibiosis, hyper parasitism and systemic acquired resistance in the host plants (Hoitink et al., 2001). BCAs have remarkable multiplication capability, thus, when the tubers treated with them, it multiplied in the exponential ratio and formed thick walled spores around the tubers to overcome with the stress from the pathogens (Bharath et al., 2005). Furtherit promoted crop growth and yield through increased uptake of nutrients and stimulation of growth of the promoting factors such as IAA and $\mathrm{GA}_{3}$ and reduction of levels of enzymes owing to colonization of roots (Idris et al., 2007; Abeysinghe, 2009).

In the light of above results, the study could be concluded that the foliar pathogens could 
be controlled using the BCAs of Trichoderma and Bacillus. T. harzianum and B. subtilis are the best BCAs against the potato foliar pathogens. During in vitro condition, following foliar application of pathogen @ 45 DAP, T. harzianum soil treatment @ 10 $\mathrm{gm} / \mathrm{kg}+B$. subtilis seed treatment @ 10 $\mathrm{gm} / \mathrm{kg}+$ is best against the emergence of Alternaria sp. From this, it is suggested for wide use against the infection of potato foliar pathogens for sustainable potato production. Further study is recommended for validation of above findings through more location specific field trials.

Table.1 Effect of BCAs on Alternaria sp infection during glass house condition

\begin{tabular}{|c|c|c|c|c|c|}
\hline Treatments & Combinations & $\begin{array}{l}\text { PDI } \\
(\%)\end{array}$ & 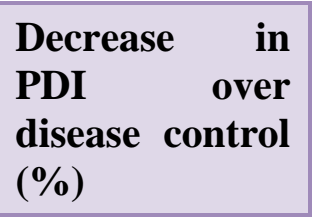 & $\begin{array}{l}\text { Yield } \\
\text { (g/pot) }\end{array}$ & $\begin{array}{lr}\text { Increase } & \text { in } \\
\text { yield } & \text { over } \\
\text { disease control } \\
(\%)\end{array}$ \\
\hline T1 & $\begin{array}{l}\text { Healthy plant }+ \text { No treatment (Negative } \\
\text { control) }\end{array}$ & 12.2 & 40.77 & 82.60 & 31.9 \\
\hline $\mathbf{T 2}$ & $\begin{array}{l}\text { Healthy plant }+ \text { Disease inoculation } \\
\text { (positive control) }\end{array}$ & 20.6 & - & 62.60 & \\
\hline T3 & $\begin{array}{l}\text { Seed treatment with } T \text {. harzianum } \\
@ 10 \mathrm{~g} / \mathrm{kg}+\text { foliar application of } \\
\text { pathogen at } 45 \mathrm{DAP}\end{array}$ & 15.5 & 24.74 & 71.30 & 13.89 \\
\hline T4 & $\begin{array}{l}\text { Soil treatment with } T \text {. harzianum @ } 10 \\
\text { g/kg + foliar application of pathogen at } \\
45 \text { DAP }\end{array}$ & 12.0 & 41.74 & 92.80 & 48.24 \\
\hline T5 & $\begin{array}{l}\text { Seed treatment with } B \text {. subtilis } 10 \mathrm{~g} / \mathrm{kg} \\
+ \text { foliar application of pathogen at } 45 \\
\text { DAP }\end{array}$ & 13.4 & 34.95 & 88.65 & 41.61 \\
\hline T6 & $\begin{array}{l}\text { B. subtilis soil treatment @ } 10 \mathrm{~g} / \mathrm{kg}+ \\
\text { foliar application of pathogen at } 45 \\
\text { DAP }\end{array}$ & 16.4 & 20.38 & 70.55 & 12.69 \\
\hline T7 & $\begin{array}{l}\text { Seed treatment with } T \text {. harzianum @ } \\
10 \mathrm{gm} / \mathrm{kg}+\text { soil treatment with } B . \\
\text { subtilis @ } 10 \mathrm{gm} / \mathrm{kg}+\text { foliar } \\
\text { application of pathogen at } 45 \mathrm{DAP}\end{array}$ & 11.1 & 46.11 & 95.15 & 51.99 \\
\hline \multirow[t]{3}{*}{ T8 } & $\begin{array}{l}\text { T. harzianum soil treatment @ } 10 \mathrm{~g} / \mathrm{kg} \\
+ \text { Seed treatment with B. subtilis @ } 10 \\
\mathrm{~g} / \mathrm{kg}+\text { foliar application of pathogen at } \\
45 \text { DAP }\end{array}$ & 8.5 & 58.73 & 125.1 & 99.68 \\
\hline & $\mathrm{SEm} \pm$ & 1.32 & 4.59 & 6.92 & 10.42 \\
\hline & $\mathrm{CD}(\mathrm{p}=0.05)$ & 4.41 & 15.36 & 23.13 & 34.85 \\
\hline
\end{tabular}


Plate.1a The antagonistic potential of $T$. harzianum (A), T. asperillum (B) and $T$. longibrachiatum $(C)$ against $A$. alternata $(1)$ and $A$. solani(2)
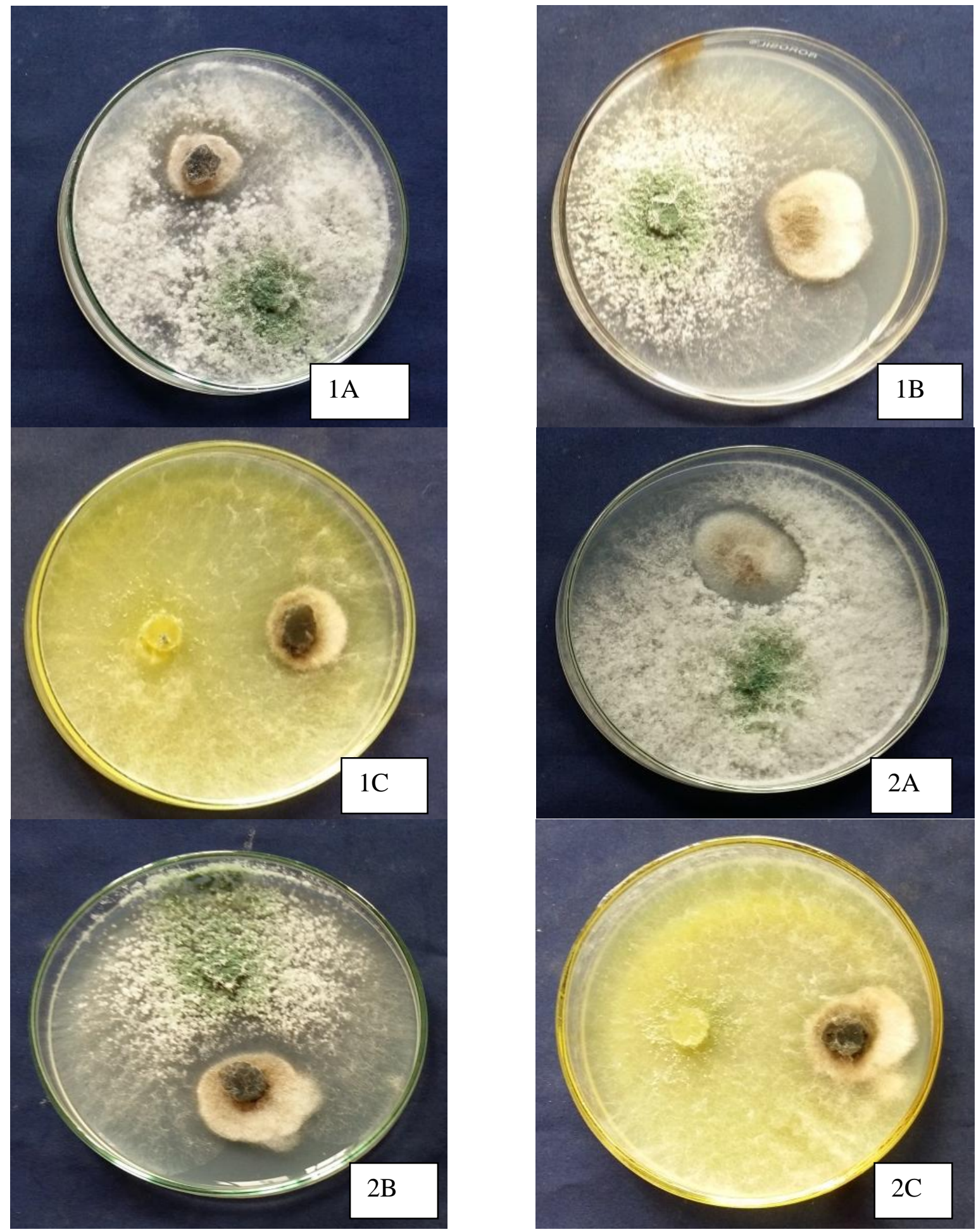
Plate.1b The antagonistic potential of $T$. harzianum (A), T. asperillum (B) and $T$. longibrachiatum $(C)$ against $C$. cassicola (3) and $C$. lunata (4)
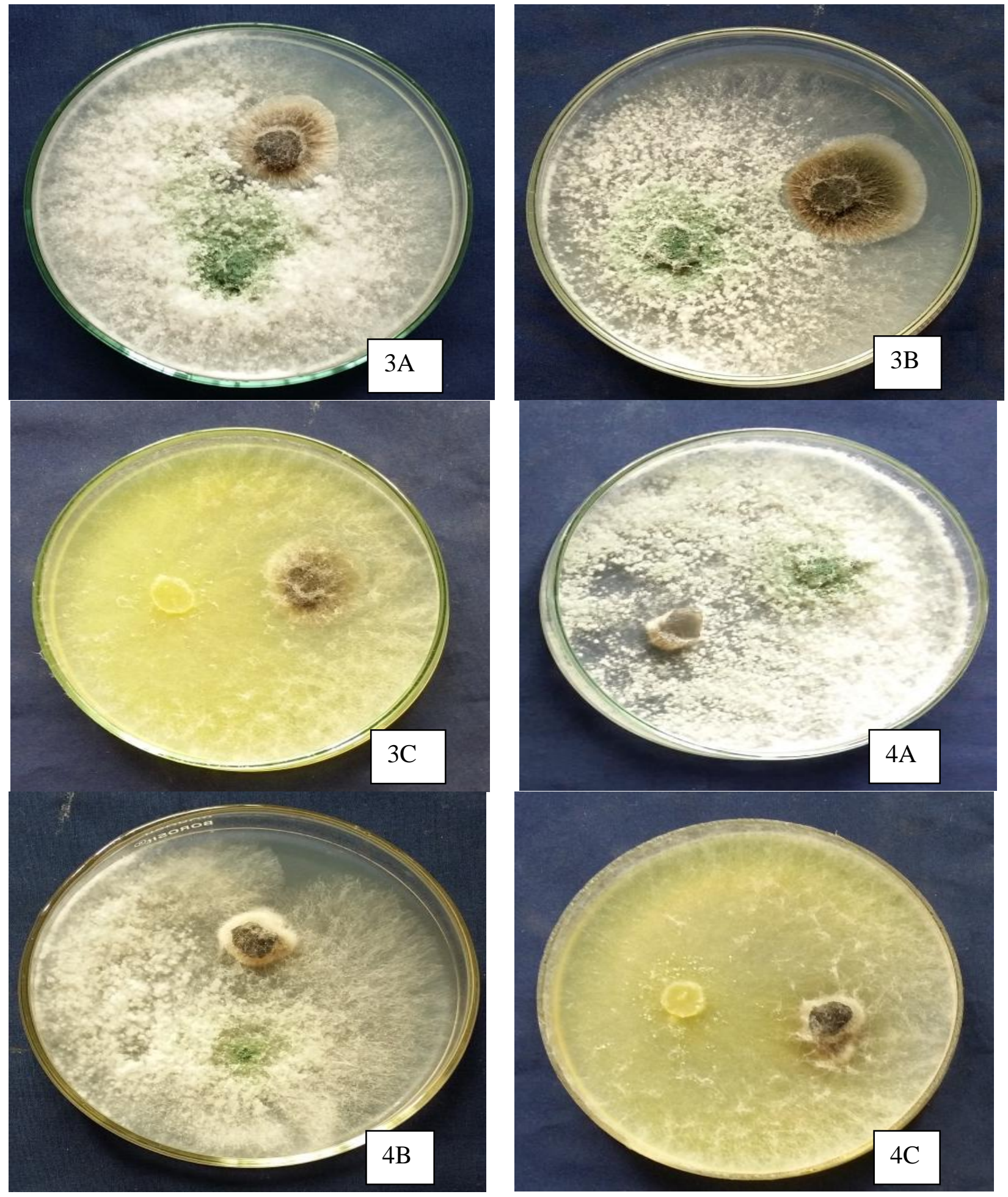
Plate.1c The antagonistic potential of T. harzianum (A), T. asperillum (B) and $T$. longibrachiatum $(C)$ against $B$. sorokiniana (5) and $P$. exigua (6)
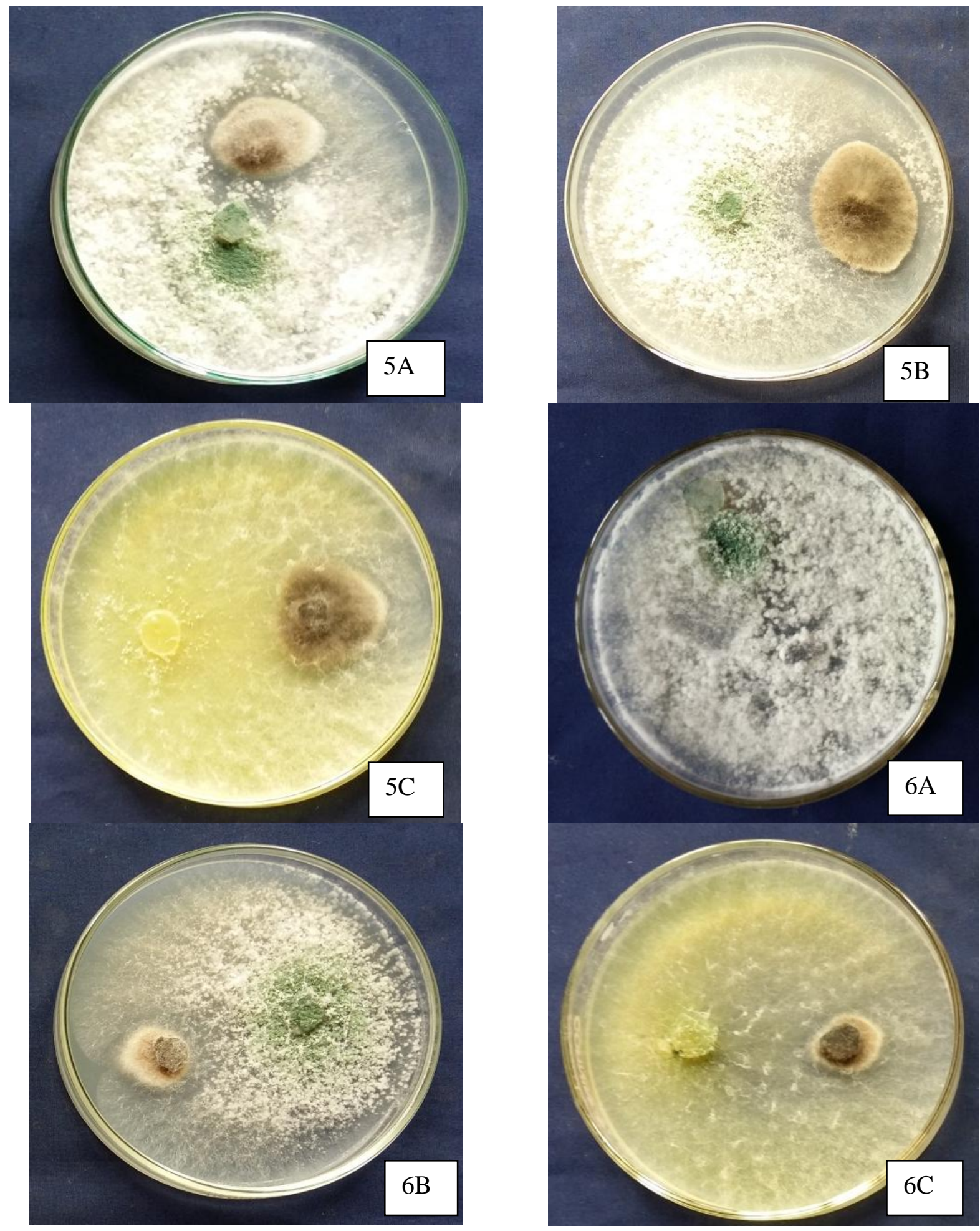
Plate.2a (A-G) Antagonistic effect of B. flexus (A), B. cereus (B), B. amyloliquefaciens $(C), B$. megaterium $(D), B$. subtilis $(E), B$. safensis $(F)$, B. siamensis $(G)$ against $A$. alternata
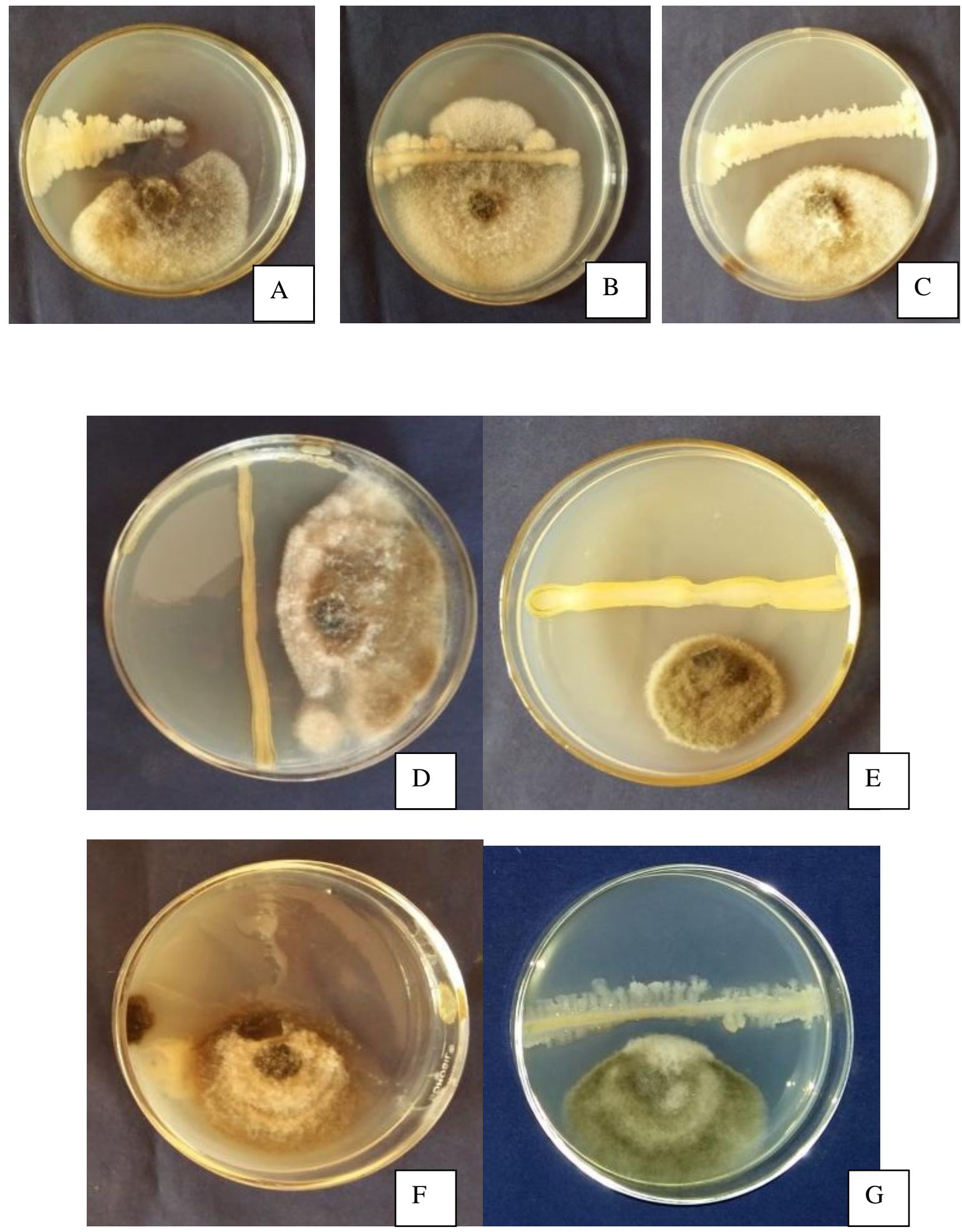
Plate 2b Antagonistic effect of B. flexus (A), B. cereus (B), B. amyloliquefaciens $(C), B$. megaterium $(D), B$. subtilis $(E), B$. safensis $(F)$, B. siamensis $(G)$ against $A$. solani
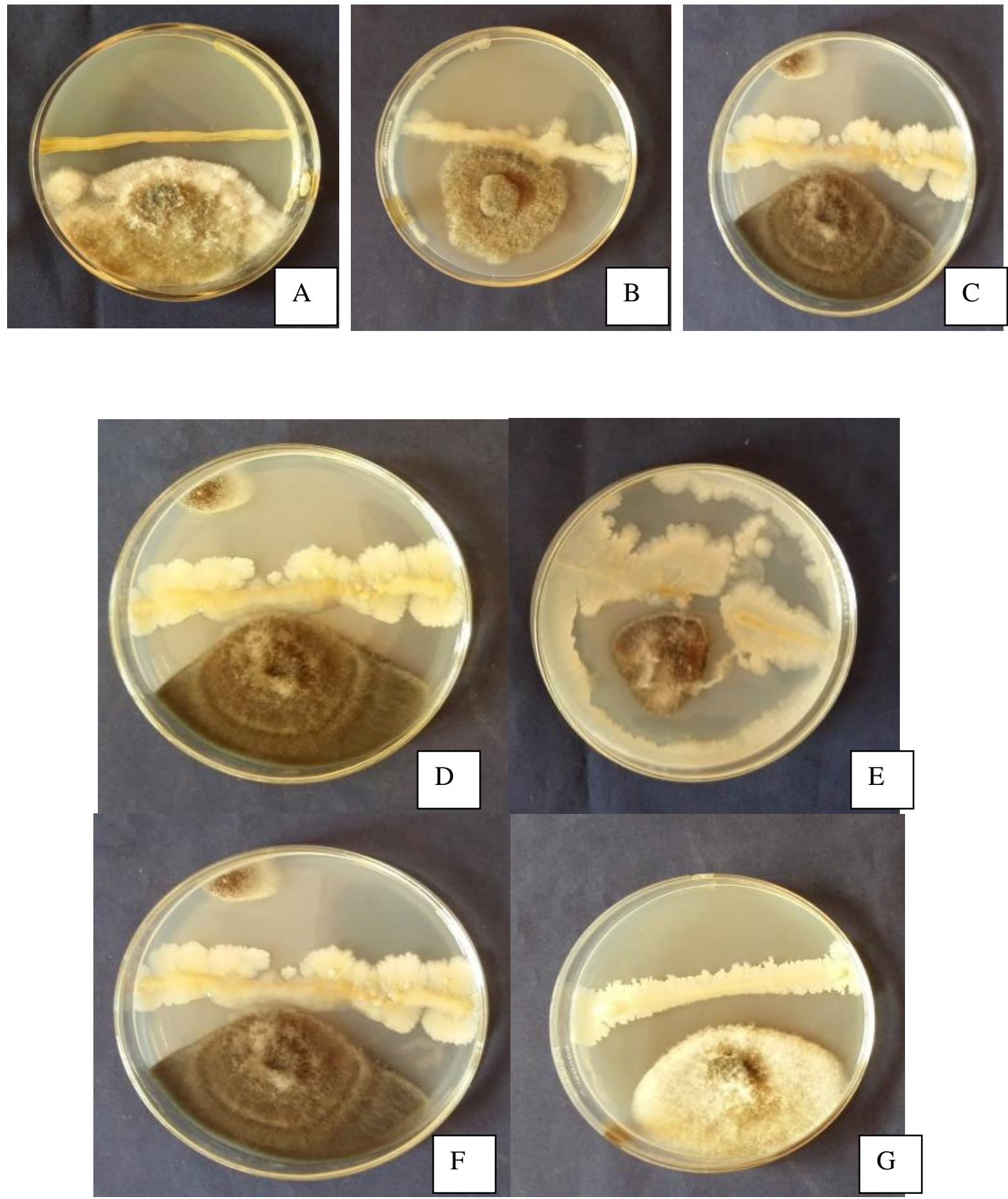
Plate 2c Antagonistic effect of B. flexus (A), B. cereus (B), B. amyloliquefaciens $(C)$, $B$. megaterium $(D), B$. subtilis $(E), B$. safensis $(F), B$. siamensis $(G)$ against $C$. lunata
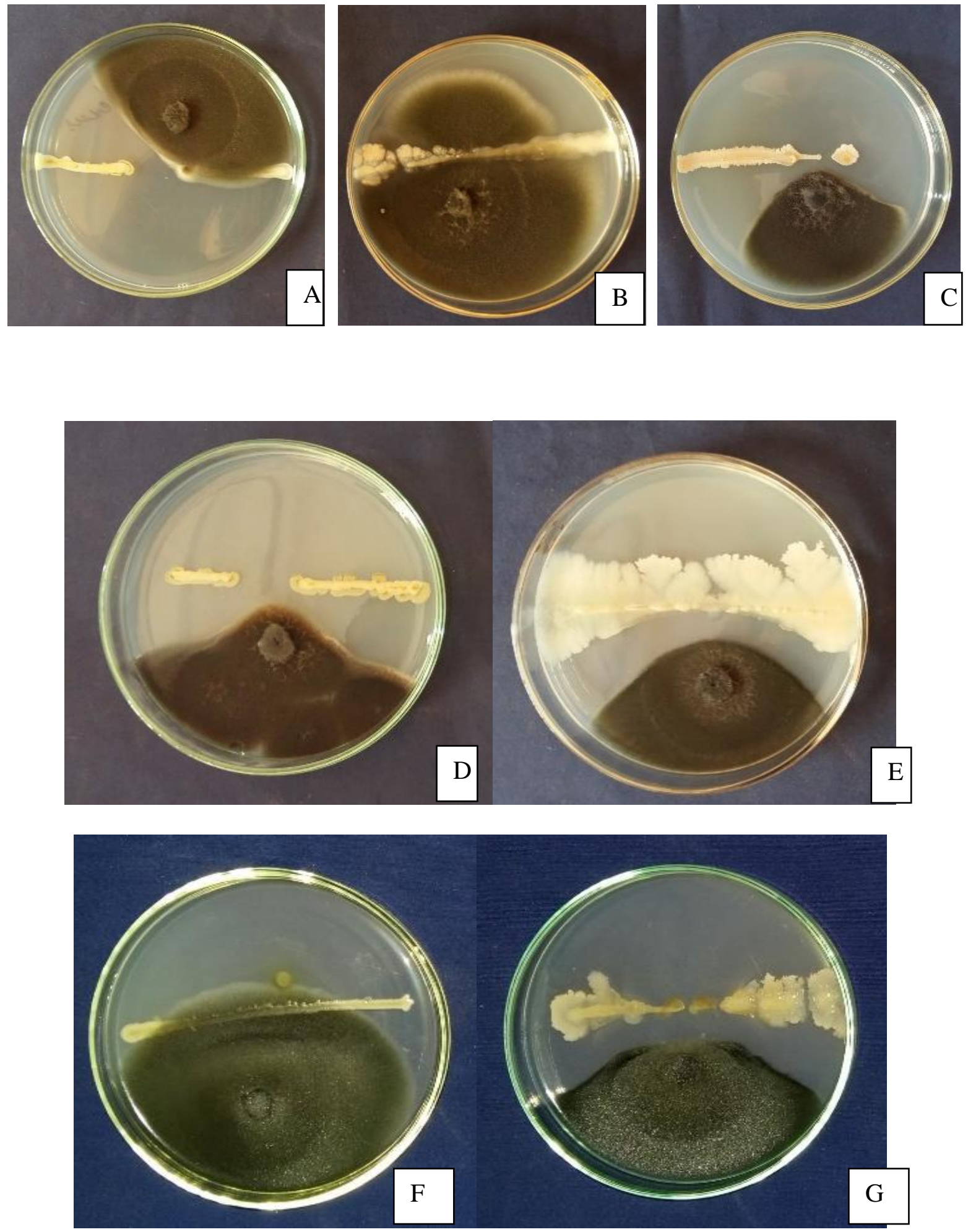
Plate 2d Antagonistic effect of B. flexus (A), B. cereus (B), B. amyloliquefaciens $(C)$, $B$. megaterium (D), B. subtilis $(E), B$. safensis $(F)$, B. siamensis $(G)$ against $C$. cassicola
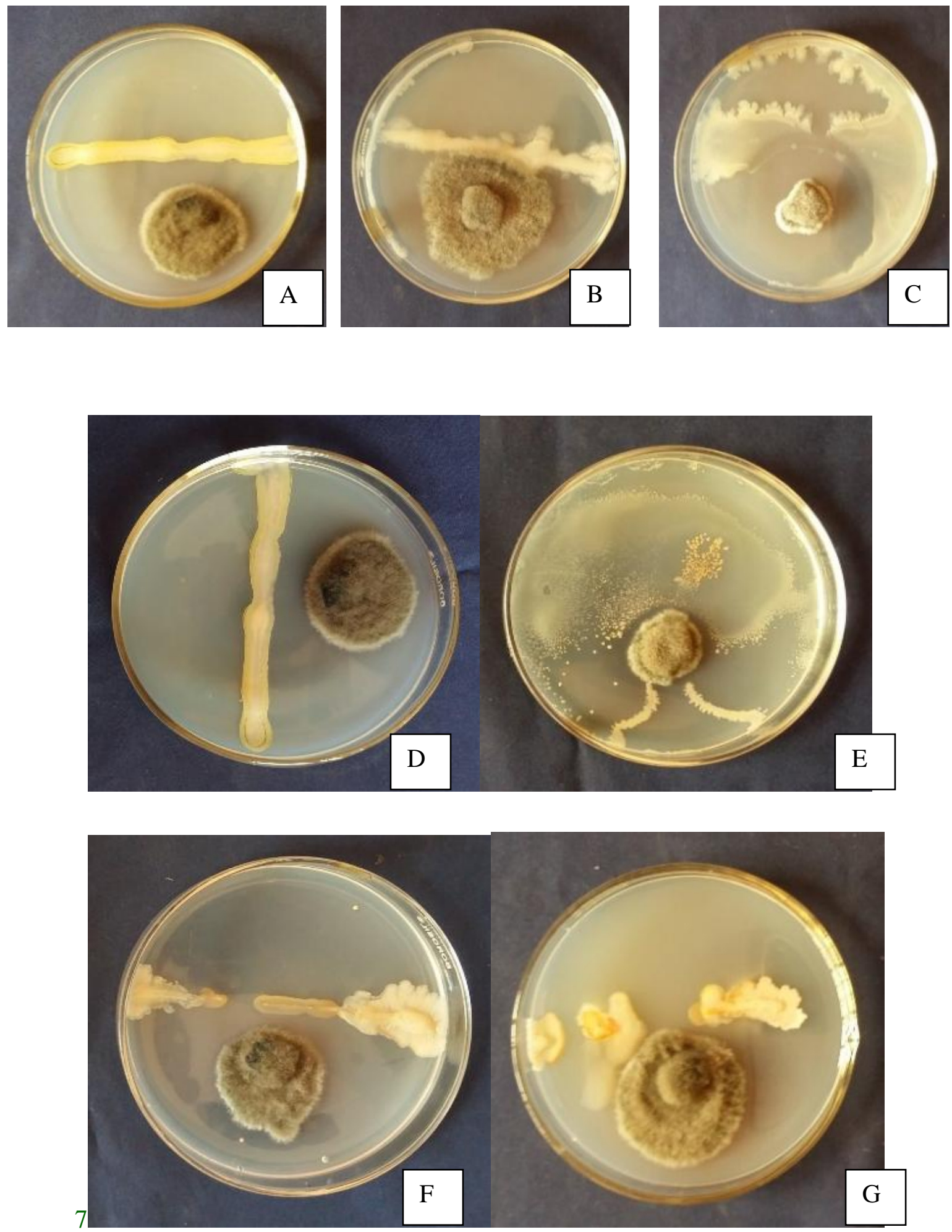
Plate 2e Antagonistic effect of different B. flexus (A), B. cereus (B), B. amyloliquefaciens $(C)$, B. megaterium $(D)$, B. subtilis $(E)$, B. safensis $(F)$, B. siamensis $(G)$ against $B$. sorokiniana
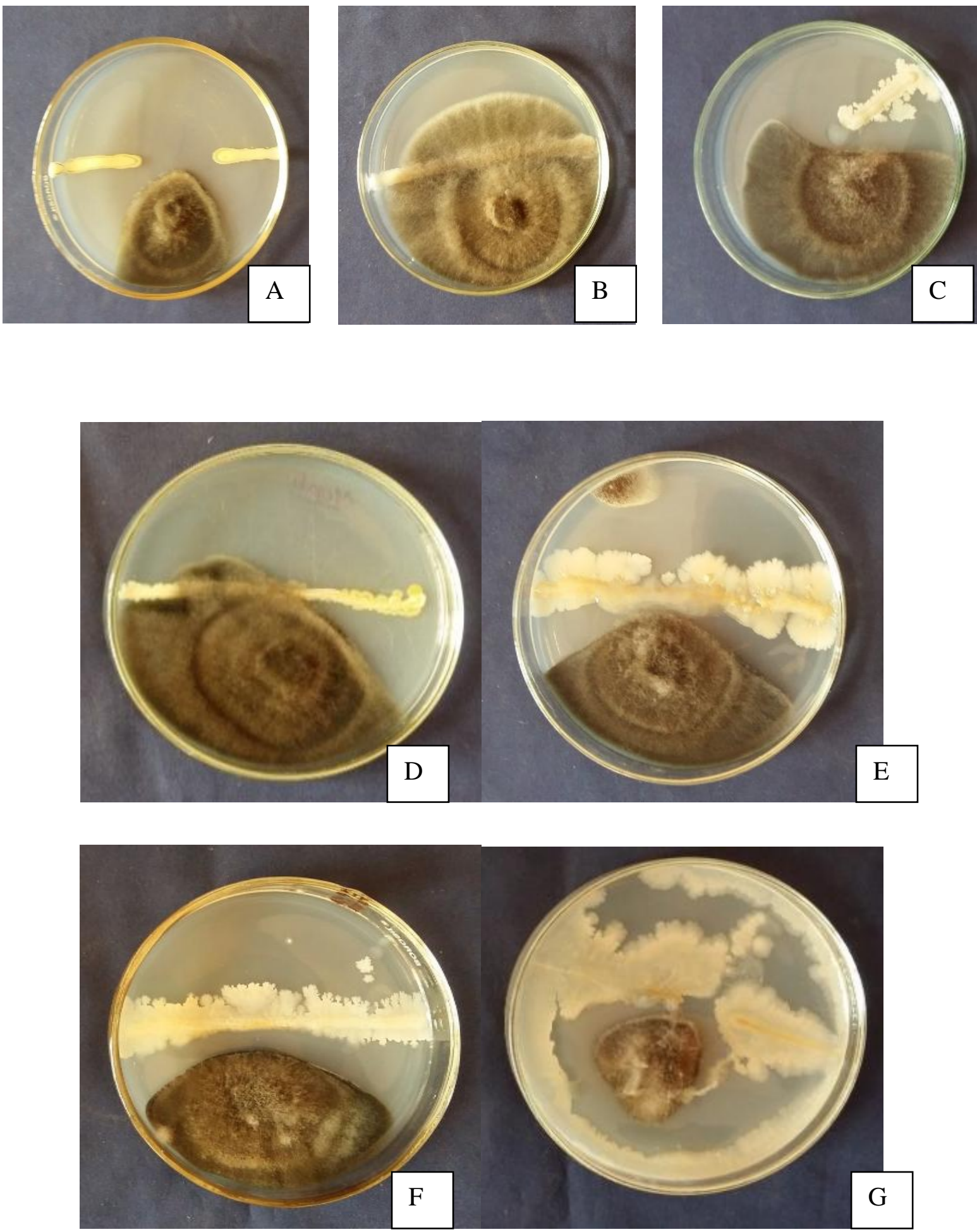
Plate 2 f Antagonistic effect of B. flexus (A), B. cereus (B), B. amyloliquefaciens $(C), B$. megaterium (D), B. subtilis $(E), B$. safensis $(F), B$. siamensis $(G)$ against $P$. exigua
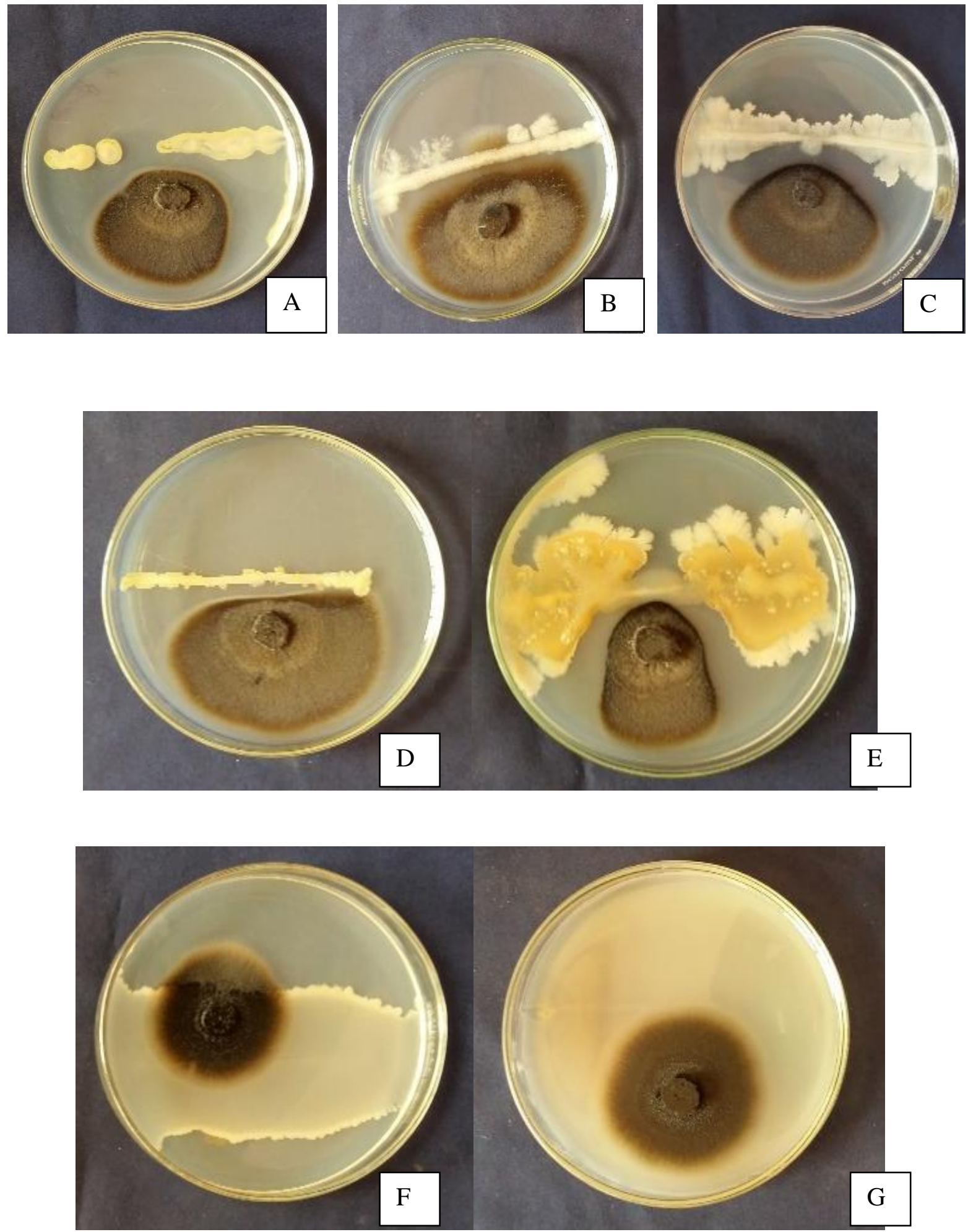
Plate.3 Glass house experiment
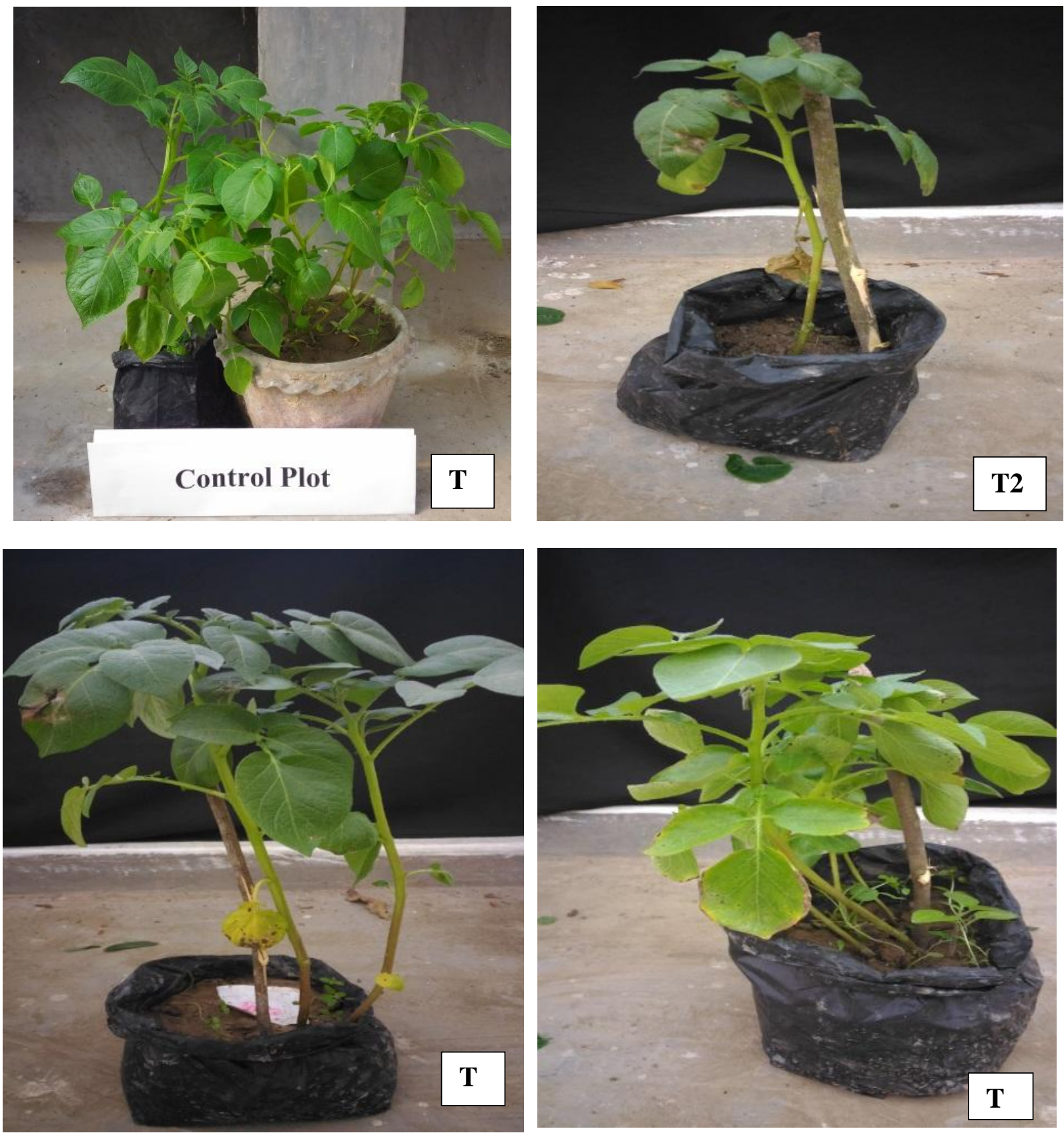

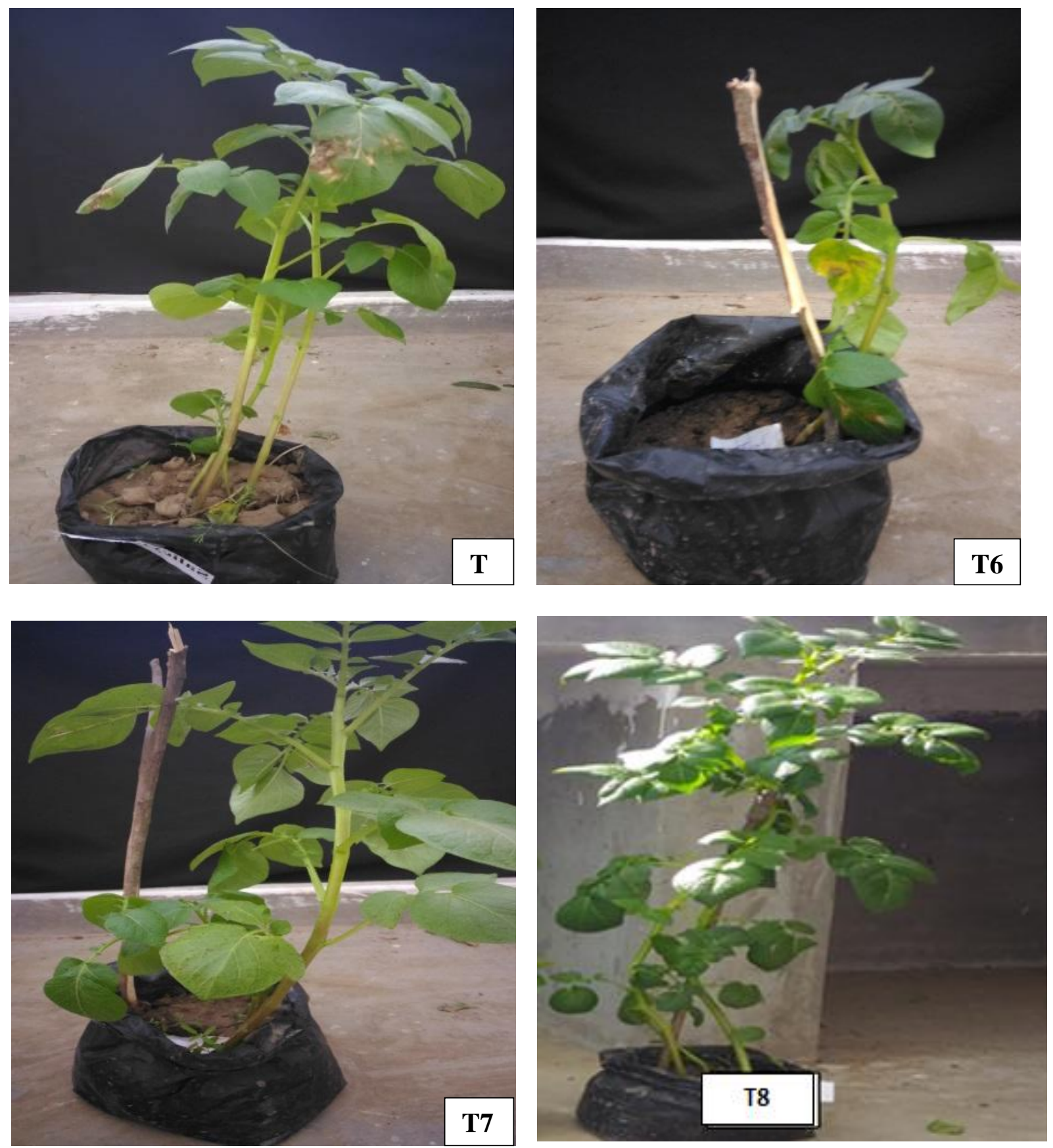
Fig.1 (a-f) Figures showing percentage inhibition in different potato foliar pathogens using Trichoderma spp.

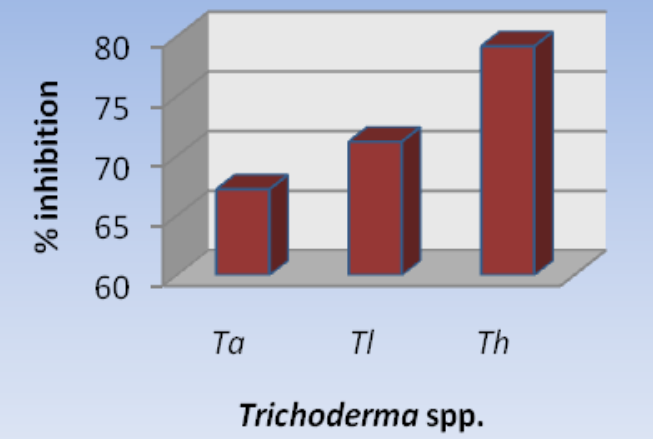

a.

Percentage inhibition in A.alternata using Trichoderma spp

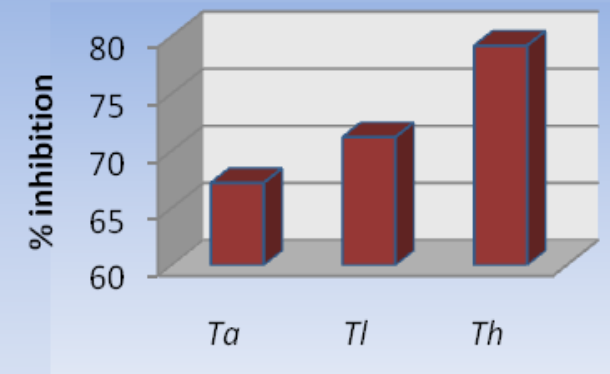

Trichoderma spp.

c. Percentage inhibition in C.cassicola using Trichoderma spp.

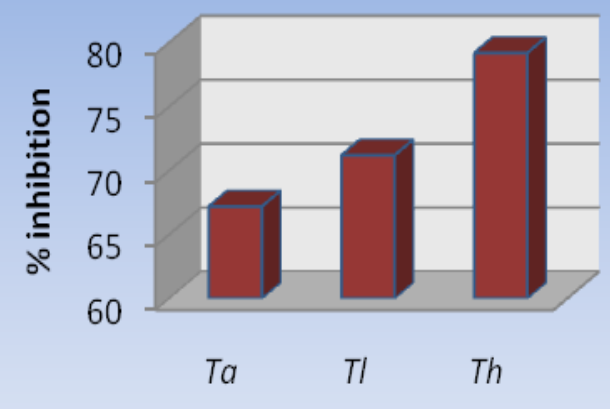

Trichoderma spp.

e. Percentage inhibition in B.sorokiniana using Trichoderma spp.

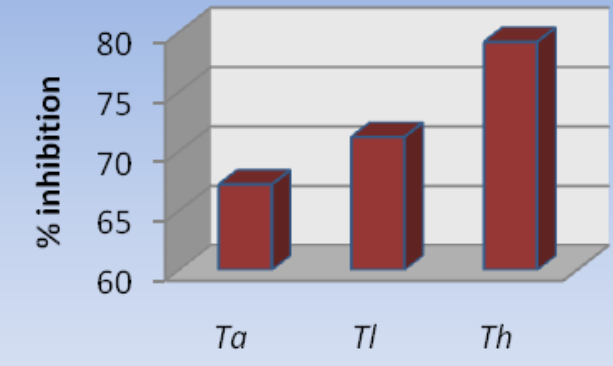

Trichoderma spp.

b. Percentage inhibition in A solani using Trichoderma spp.

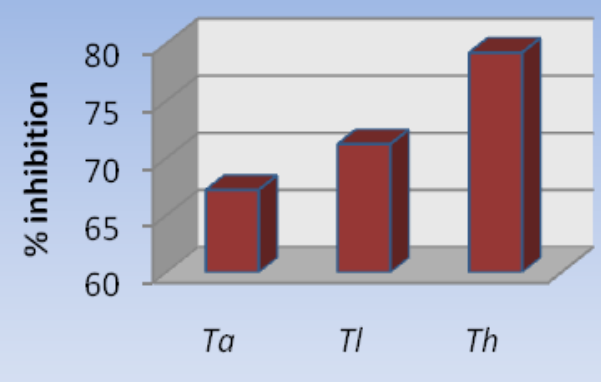

Trichoderma spp.

d. Percentage inhibition in C.lunata using Trichoderma spp.

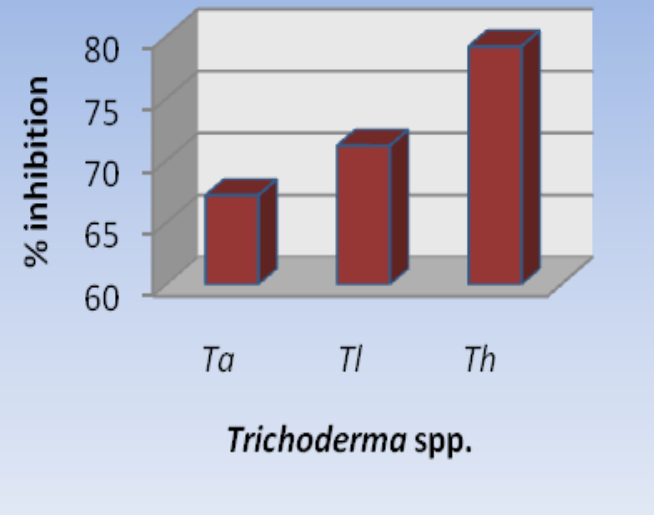

f. Percentage inhibition in P.exigua using Trichoderma spp. 
Fig.2 (a-f) Figures showing percentage inhibition in different potato foliar pathogens using Bacillus spp.

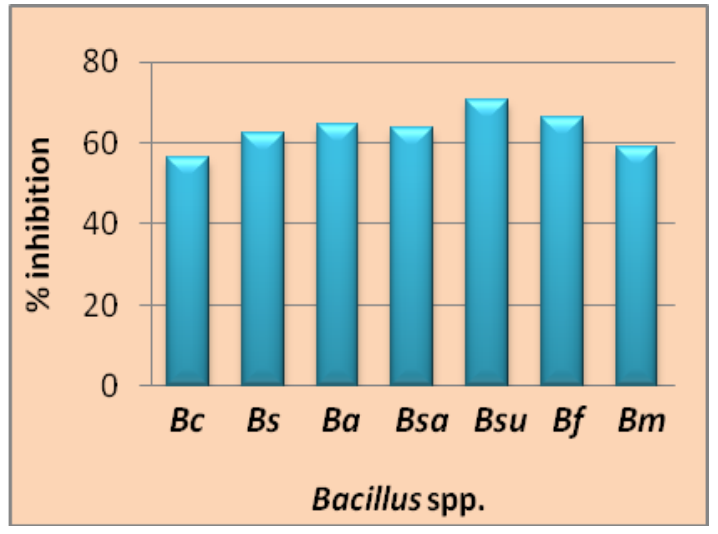

a. Percentage inhibition in A.alternata using Bacillus spp.

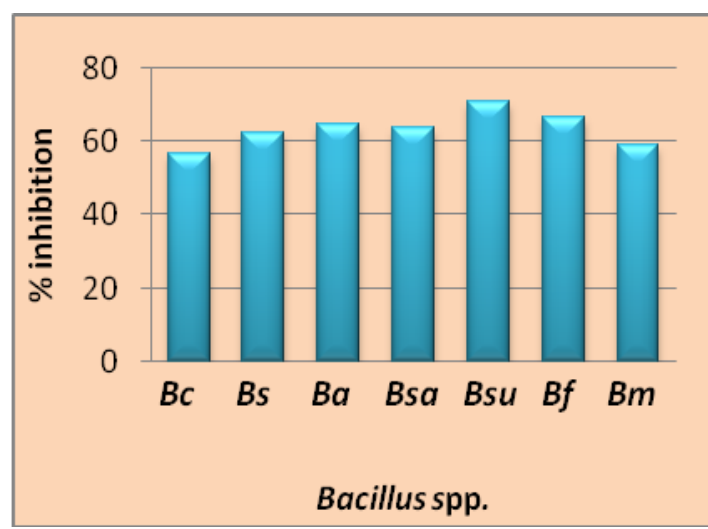

c. Percentage inhibition in C.lunata using Bacillus spp.

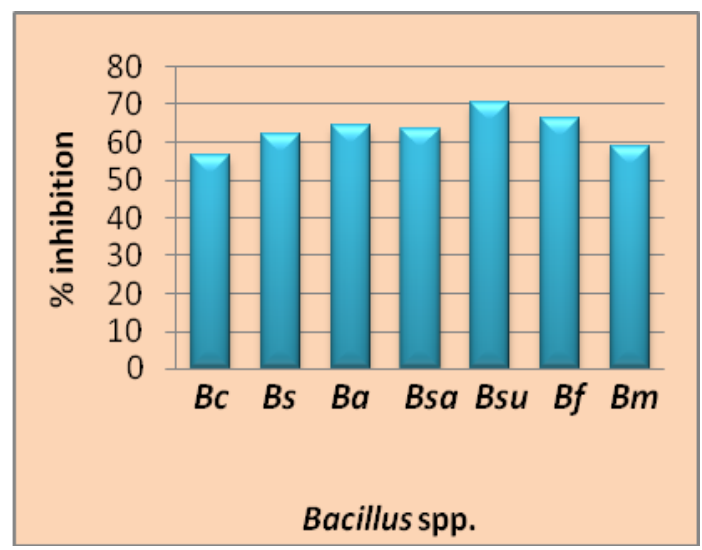

e. Percentage inhibition in B. sorokiniana using Bacillus spp.

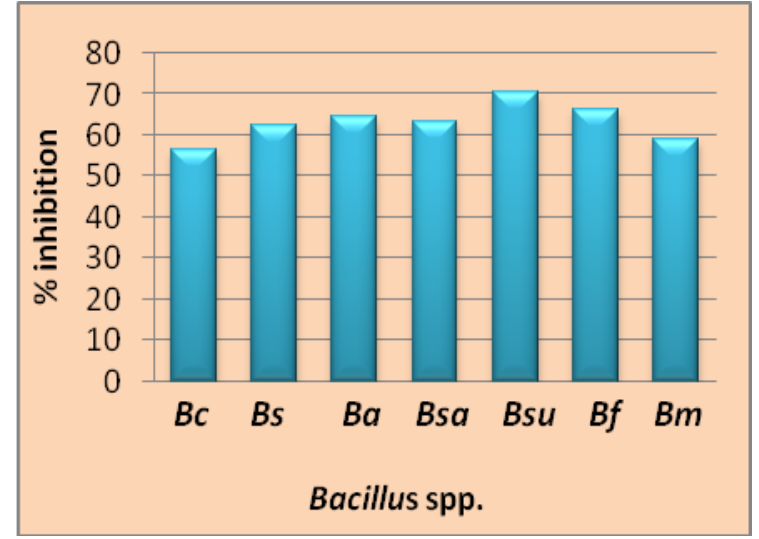

b. Percentage inhibition in A.solani using Bacillus spp.

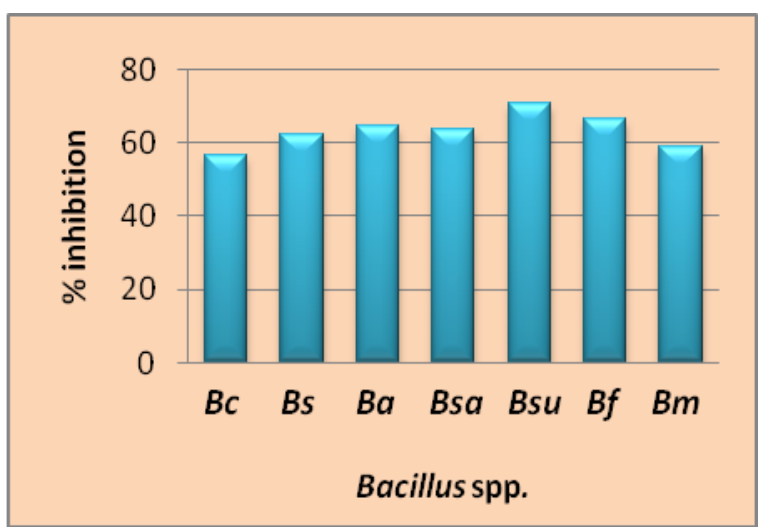

d. Percentage inhibition in C.cassicola using Bacillus spp.

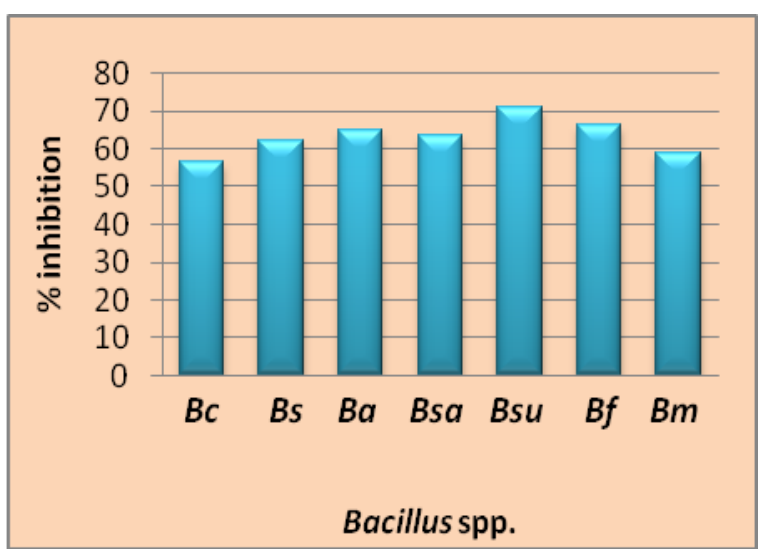

f. Percentage inhibition in $P$. exigua using Bacillus spp. 
In conclusion, out of three Trichoderma spp. (T. asperillum, T. longibrachiatum and $T$. Harzianum), T. harzianum was the best biocontrolling agent against the foliar pathogens. The inhibition rate was $54-72 \%$ in $A$. alternata, $49.2-76 \%$ in A. solani, $39.2-71.2 \%$ in C. lunata, $74.0-79.2 \%$ in C. cassicola, 41.2-59.2\% in B. sorokiniana and $67.2-79.2 \%$ in $P$. exigua. Out of seven Bacillus spp. ( $B$. cereus, $B$. siamensis, $B$. amyloliquefaciens, $B$. safensis, $B$. subtilis, $B$. flexus and $B$. Megaterium, $B$. subtilis was best biocontrolling agent against the foliar pathogens except for $C$. cassicola and B. sorokiniana where $B$. amyloliquefaciens has given best result. The inhibition rate was $27.45-52.72 \%$ in A. alternata, 26.75-56.60\%, in A. solani, $34.83-66.02 \%$ in $C$. lunata, $48.30-68.51 \%$ in C. cassicola, $29.46-45.53 \%$ in B. sorokiniana, $56.55-70.75 \%$ in P. exigua.

During in-vivo assessment of bio-control agents, the PDI was found $8.5 \%$ with $T$. harzianum soil treatment @10 gm/kg + Seed treatment with $B$. subtilis @ $10 \mathrm{gm} / \mathrm{kg}+$ foliar application of pathogen at 45 days after planting (DAP),11.1\% with Seed treatment with T. harzianum @ $10 \mathrm{gm} / \mathrm{kg}+$ soil treatment with B. subtilis @ 10 gm/ $/ \mathrm{kg}+$ foliar application of pathogen at 45 DAP, $12.0 \%$ with soil treatment with $T$. harzianum @10 $\mathrm{gm} / \mathrm{kg}+$ foliar application of pathogen at 45 DAP, $12.2 \%$ in healthy plant + no treatment (negative control), $13.4 \%$ with seed treatment with $B$. subtilis $10 \mathrm{gm} / \mathrm{kg}+$ foliar application of pathogen at 45 DAP, $15.5 \%$ with seed treatment with T. harzianum @ $10 \mathrm{~g} / \mathrm{kg}+$ foliar application of pathogen at 45 DAP, $16.4 \%$ with B. subtilis soil treatment @ $10 \mathrm{gm} / \mathrm{kg}+$ foliar application of pathogen at 45 DAP in comparison with $20.4 \%$ in healthy plant + disease inoculation (positive control).Thus, from this study, it is clear that combination of T. harzianum soil treatment @ $10 \mathrm{gm} / \mathrm{kg}+$ seed treatment with $B$. subtilis @ $10 \mathrm{gm} / \mathrm{kg}+$ foliar application of pathogen at 45 DAP is best against the potato foliar disease.

\section{References}

Abdallah, B., Frikha, GO., and Tounsi, S., 2015. Bacillus amyloliquefaciens strain $32 \mathrm{a}$ as a source of lipopeptides for biocontrol of Agrobacterium tumefaciens strains. Journal Of Applied Microbiology. 119: 196-207.

Abeysinghe, S., 2009. Efficacy of combine use of biocontrol agents on control of Sclerotium rolfsii and Rhizoctonia solani of Capsicum annuum. Archives of Phytopathology and Plant Protection. 42 (3): 221-227.

Bell, DK., Wells, HD., and Markham, CR. 1982. In-vitro antagonism of Trichoderma spp. against six fungal plant pathogens.Phytopathology.72: 379-382.

Bharath, BG., Lokesh, S and Shetty, HS. 2005. Effects of fungicides and bioagents on seed mycoflora, growth and yield of watermelon. Integral Biology Science. 9:75-78

Booth, C., and Sutton, BC., 1984. Fusarium pallidoroseum, the correct name for $F$. semitectum. Transaction of the British Mycology Society. 23: 702-704.

Bruce, A., Srinivasan, U., Staines,HJ., and Highley, TL., 1995. Chitinase and laminarinase production in liquid culture by Trichoderma spp. and their role in biocontrol of wood decay fungi. International Biodeteriortion and Biodegradation. 35 (4): 337-353.

Cao, Y., Zhang, ZH., Ling, N., Yuan, YJ., Zheng, XY., Shen, B., and Shen., QR., 2011. Bacillus subtilis SQR 9 can control Fusarium wilt in cucumber by colonizing plant roots. Biology and Fertility of Soils. 47: 495-506.

Chen, GC. and Johnson, BR., 1983. Improved colorimetric determination of cell wall chitin in wood decay fungi. Applied and Environment Microbiology. 46: 13-16.

Chowdhry, PN., Lal, SP., Mathur, N., and 
Singh, DV., 2000. Manual on identification of plant pathogenic and biocontrol fungi of agricultural importance. Center of Advanced Studies in Plant Pathology, Indian Agricultural Research Institute, New Delhi, 149 pp.

Dennis, C., and Webster, J., 1971. Antagonistic properties of species groups of Trichoderma viride. Production of Non- volatile antibiotics. Transaction of the British Mycology Society.57: 25-39.

Djébali, N., and Belhassen, T., 2010.Field study of the relative susceptibility of eleven potato (Solanum tuberosumL.) varieties and the efficacy of two fungicides against Rhizoctonia solani attack. Crop Protection. 29: 9981002pp.

Foolad, MR., Ntahimpera, N., Christ, BJ., and Lin, GY., 2000. Comparison of field, green house and detached-leaflet evaluation of tomato germplasm for early blight resistance. Plant Disease.84: 967-972.

Fujimoto, A., and Kupper,KC.,2016. Production of antifungal compounds and hydrolytic enzymes by bacillus spp. as mechanisms of action against Phyllosticta citricarpa. IOSR Journal Of Agriculture Vetenary Science. 9 (11): 19-27.

Gupta,AK.,2007. Potato and potato productscultivation, seed production, manuring, harvesting, organic farming, storage and processing. Published by- NPCS Board of consultants and Engineers. NIIR Project Consultancy Services, New Delhi- 110 007, 1-195pp.

Haran, S., Schikler, H., and Chet, I.,1996. Molecular mechanisms of lytic enzymes involved in the biocontrol activity of Trichoderma harzianum. Microbiology. 142: 2321-2331.
Hausladen, H., and Leiminger, J., 2011. Disease-orientated threshold values as tool for effective early blight control. $13^{\text {th }}$ Euro Blight workshop.

Hoitink, HAJ., Krause, MS., Han, DY., 2001. Spectrum and mechanism of plant diseases control with compost. In: Peter JS, Brain AK (eds). Compost utilization in horticultural cropping systems. Lewis publishers, Boca Raton, pp 263

Idris, EE., Iglesias, DJ., Talon, M., and Borriss, R., 2007. Tryptophandependent production of indole-3acetic acid (IAA) affects level of plant growth promotion by Bacillus amyloliquefaciens. Molecular PlantMicrobe Interaction. 19: 250-256.

Liu, J., He, D., Li, X., Gao, S., We, H., Liu, W., and Gao, X., 2010. $\gamma$ Polyglutamic acid ( $\gamma$-PGA) produced by Bacillus amyloliquefaciens $\mathrm{C} 06$ promoting its colonization on fruit surface. International Journal of food microbiology. 142: 190-197.

Mannanov, RN., and Sattarova, RK., 2001. Antibiotics produced by Bacillus bacteria. Chemistry of Natural Compound.37(2):117-23.

Mayee, CD., and Datar, VV., 1986. Phytopathometry, Technical Bulletin1 (Special Bulletin-3) Marathwada Agricultural University, Parbhani, Maharashtra, India, $95 \mathrm{pp}$.

Mishra, S., and Singh, HB., 2012. Glimpses of Phytopathology for Sustainable Agriculture, AB Publication Mayur Vihar, New Delhi, India, 37-55pp.

Morton, DT., and Stroube, NH., 1955. Antagonistic and stimulatory effect of microorganism upon Sclerotium rolfsii. Phytopathology.45: 419-420.

Nandakumar, R., Babu, S., Viswanathan, R., Sheela, J., Raguchander, T., Samiyappan, R., 2001. A new bioformulation containing plant 
growth promoting rhizobacterial mixture for the management of sheath blight and enhanced grain yield in rice. Biocontrol. 46 (4): 493510.

Pal,KK., and Gardener, MB., 2006. Biological Control of Plant Pathogens. Plant Health Instructor.1-25 pp.

Pandey, A. 2010. Antagonism of Two Trichoderma species against Alternaria alternata on Capsicum frutescens. Journal of Experimental Science. 1(5): 18-19.

Podile, AR., Prasad, GS., and Dube, HC.,1987. Partial Characterization of the Antagonistic Principle of Bacillus subtilis AF1. Journal of Biological Control. 1: 60-5.

Rangaswami, G., 1958. An agar block technique for isolating soil micro organisms with special reference to Pythiaceous fungi. Scientific Culture. 24: 85.

Rani, S., Singh, R., and Gupta, S.,2017. Development of integrated disease management module for early blight of tomato in Jammu. Journal of Pharmacogonsy and Photochemistry.
6(2): 268-273.

Souja, A., Cruz, JC., Susa, NR., Procopio, ARL., and Silva, GF.,2014. Endophytic bacteria from banana cultivars and their antifungal activity.Geneticsand Molecular Research. 13(4): 8661-8670.

Suleiman, RA., Rosentrater, KA., and Chove, B., 2016. Periodic physical disturbance: an alternative method for controlling Sitophilus zeamais (maize weevil) infestation. Insects. 7: 51.

Thilagavathi, R., Saravanakumar, D., Ragupathi, N., Samiyappan, R., 2007. A combination of biocontrol agents improves the management of dry root rot (Macrophomina phaseolina) in green gram. Phytopathologia Mediterrenea. 46 (2): 157167.

Vurro, M., and Gressel, J., 2006. An integrated European approach to biological control of plant diseases and weeds. In: An Ecological and Societal Approach to Biological Control. Springer, Netherlands. 257$274 \mathrm{pp}$.

\section{How to cite this article:}

Jayashree Bhattacharjee, Debashre Bhattacharjee and Amitava Basu. 2019. Evaluation of Biocontrolling Agents against Potato Foliar Pathogens. Int.J.Curr.Microbiol.App.Sci. 8(03): 13441364. doi: https://doi.org/10.20546/ijcmas.2019.803.159 